\title{
A comparative study of different PCR-based DNA fingerprinting techniques for typing of the Acinetobacter calcoaceticus-A. baumannii complex
}

\author{
J. VILA, M. A. MARCOS and M. T. JIMENEZ DE ANTA \\ Department de Microbiologia, Hospital Clinic, Facultat de Medicina, Universitat de Barcelona, Villarroel 170, \\ 08036 Barcelona, Spain
}

\begin{abstract}
Different PCR-based DNA fingerprinting techniques were evaluated for typing 26 clinical isolates belonging to the Acinetobacter calcoaceticus-A. baumannii complex. Seven isolates belonged to a previously defined outbreak while 19 isolates were unrelated epidemiologically. The PCR-based DNA fingerprinting techniques used were: (i) repetitive extragenic palindromic (REP) PCR; (ii) enterobacterial repetitive intergenic consensus (ERIC) PCR; (iii) randomly amplified polymorphic DNA with M13 forward primer; (iv) restriction analysis of the amplified 16S rRNA gene (ARDRA-16S); and (v) restriction analysis of an amplified region containing the 16S-23S rRNA spacer region and part of the 23S rRNA gene (ARDRA 23S + spacer). The discrimination index for the PCR-based DNA fingerprinting techniques was: 0.99 for REP; 0.94 for ERIC; 0.87 for M13; 0.60 for ARDRA-16S digested with $H p a$ II and <0.50 for ARDRA 23S + spacer. It was concluded that REP-PCR possessed high discriminatory power and reproducibility in comparison with the other PCR-based DNA fingerprinting techniques, and is a simple and rapid typing method for use in epidemiological studies of isolates belonging to the $A$. calcoaceticus- $A$. baumannii complex.
\end{abstract}

\section{Introduction}

Nosocomial outbreaks of infection involving members of the Acinetobacter calcoaceticus-A. baumannii complex have been reported frequently [1-6]. An ability to distinguish isolates of the A. calcoaceticus-A. baumannii complex is useful for investigating the source of outbreaks of infection, the relationship between isolates from different patients and the environment, and the identities of multiple isolates from the same patient. Methods that have been used include antibiotic resistance patterns [7], phage typing [8], total plasmid content [9], serological typing [10], whole-cell $[11,12]$ and cell-envelope $[13,14]$ protein electrophoresis, ribotyping [15], and low-frequency restriction analysis of chromosomal DNA $[16,17]$. Some of these techniques have a low discriminatory power, whereas others require a considerable amount of time, equipment and expertise to perform. In addition, with some of these techniques, various in-vivo or in-vitro conditions can change the phenotypic characteristics of certain organisms [18] and can generate variable results. Although ribotyping and low-frequency restriction analysis of chromosomal DNA have a good discrimination index, they are complex to perform.

Received 19 June 1995; revised version accepted 1 Nov. 1995.

Corresponding author: Dr J. Vila.
Numerous reports have also demonstrated that PCR is useful for typing many micro-organisms [19-21]. Several PCR-based DNA fingerprinting techniques have been used to study nosocomial outbreaks involving members of the $A$. calcoaceticus- $A$. baumannii complex, including arbitrarily primed (AP) PCR with primer M13 [22,23], enterobacterial repetitive intergenic consensus (ERIC) PCR [24] and repetitive extragenic palindromic (REP) PCR [25]. However, these techniques have not been compared thus far for their reproducibility and discriminatory power by fingerprinting isolates of a single collection. The purpose of this study was to evaluate several PCR-based DNA-fingerprinting techniques - APPCR with primer M13, ERIC-PCR, REP-PCR and amplified rDNA restriction analysis (ARDRA) - for typing strains belonging to the A. calcoaceticus- $A$. baumannii complex.

\section{Materials and methods}

\section{Bacterial strains}

In total, 26 clinical isolates belonging to the $A$. calcoaceticus-A. baumannii complex were analysed, with initial identification based on the biochemical criteria established by Bouvet and Grimont [26]. The epidemiology of the isolates had been examined previously by low-frequency restriction analysis of 
chromosomal DNA [17]. Of the 26 strains, seven belonged to the same outbreak and 19 were unrelated epidemiologically.

\section{$D N A$ preparation and $P C R$ reaction conditions}

Bacteria were grown on MacConkey's agar overnight. Half a colony of each isolate was suspended in $25 \mu 1$ of distilled sterile $\mathrm{H}_{2} \mathrm{O}$, and boiled for $10 \mathrm{~min}$. After a short centrifugation, $25 \mu \mathrm{l}$ of a reaction mixture containing $20 \mathrm{mM}$ Tris- $\mathrm{HCl}(\mathrm{pH} 8.8), 100 \mathrm{mM} \mathrm{KCl}$, $3.0 \mathrm{mM} \mathrm{MgCl} 2$, gelatin $0.1 \% \mathrm{w} / \mathrm{v}, 400 \mu \mathrm{M}$ dNTPs, and $1 \mu \mathrm{M}$ of the appropriate primers, except as noted below were added, together with $2.5 \mathrm{U}$ of $\mathrm{Taq}$ polymerase (Gibco-BRL). The mixture was overlaid with oil and amplified by PCR (see below). To amplify rDNA, the extracted DNA was purified to a higher level with the InstaGene DNA Purification Matrix (BioRad), used according to the manufacturer's instructions. The extracted DNA was diluted 1 in $10,25 \mu 1$ of the diluted DNA was boiled for $10 \mathrm{~min}$, and $25 \mu \mathrm{l}$ of the reaction mixture described above was added together with Taq polymerase.

\section{$A P-P C R$}

AP-PCR fingerprinting was performed as described previously [24], with a primer concentration of $0.25 \mu \mathrm{M}$ and the following PCR program: two cycles of $94^{\circ} \mathrm{C}$ for $5 \mathrm{~min}, 40^{\circ} \mathrm{C}$ for $5 \mathrm{~min}$, and $72^{\circ} \mathrm{C}$ for $5 \mathrm{~min}$; followed by 40 high-stringency cycles of $94^{\circ} \mathrm{C}$ for $1 \mathrm{~min}, 60^{\circ} \mathrm{C}$ for $1 \mathrm{~min}$ and $72^{\circ} \mathrm{C}$ for $2 \mathrm{~min}$. Amplified DNA products were resolved by electrophoresis on agarose $2 \%$ w/v gels.

\section{REP-PCR and ERIC-PCR}

The primers used had the following sequences: 5'IIIGCGCCGICATCAGGC-3' and 5'-ACGTCTTATCAGGCCTAC-3' (REP); and 5'-ATGTAAGCTCCTGGGGATTCAC-3' and 5'-AAGTAAGTGACTGGGGGT-3' (ERIC). PCR amplification was performed with 30 cycles of $94^{\circ} \mathrm{C}$ for $1 \mathrm{~min}, 40^{\circ} \mathrm{C}$ (REP) or $52^{\circ} \mathrm{C}$ (ERIC) for $1 \mathrm{~min}$ and $65^{\circ} \mathrm{C}$ for $8 \mathrm{~min}$, with a single final extension of $65^{\circ} \mathrm{C}$ for $16 \mathrm{~min}$. Samples $(20 \mu \mathrm{l})$ of each PCR end-product were analysed on agarose $2 \% \mathrm{w} / \mathrm{v}$ gels.

Restriction analysis of the amplified $16 S \mathrm{rRNA}$ gene and an amplified region containing the $16 S-23 S$ rRNA spacer region and part of the $23 S$ rRNA gene

The primers used to amplify the $16 \mathrm{~S}$ rRNA gene were 5'-TACCTTGTTACGACTT-3' and 5'-AGAGTTTGATCITGGA-3'. For amplification of the spacer region between the genes coding for $16 \mathrm{~S}$ and $23 \mathrm{~S}$ rRNA and a portion of the gene coding for 23S rRNA gene, the primers used were 5'-AAGTCGTAACAAGGTA-3' and 5'-TACTGGTTCACTATCGGTCA-3'. In both cases,
PCR was performed with 30 cycles of $94^{\circ} \mathrm{C}$ for $70 \mathrm{~s}$, $55^{\circ} \mathrm{C}$ for $150 \mathrm{~s}$, and $72^{\circ} \mathrm{C}$ for $180 \mathrm{~s}$. A $15-\mu \mathrm{l}$ portion of each PCR end-product was digested, according to the manufacturer's instructions, with $1 \mathrm{U}$ of $H i n \mathrm{fI}, H p a \mathrm{II}$, Taq I, Alu I, (Promega), Rsa I, HphI, Hha I, Nla IV (New England Biolabs) or Dde I (Boehringer Mannheim) Restriction fragment length polymorphisms (RFLPs) were determined after electrophoresis of the restricted DNA on agarose $1 \% \mathrm{w} / \mathrm{v}$ plus NuSieve agarose $1.5 \% \mathrm{w} / \mathrm{v}$.

\section{Determination of reproducibility}

Reproducibility was defined as the ability of a technique to yield the same result when the same strain was tested three times on different days with different DNA preparations, and was expressed as the percentage of strains that gave the same profile in three separate experiments.

\section{Results}

$A P-P C R$

DNA fingerprints generated with M13 forward primer are shown in Fig. 1A. Ten different banding patterns were distinguished (Table 1), composed of 2-4 DNA fragments of $0.5-2.1 \mathrm{~kb}$. PCR profiles of the seven strains involved in the outbreak showed the same patterns (strain nos. 41 and 661 in Figs 1 and 2). The small differences in fingerprints caused by minor DNA fragments were demonstrated repeatedly.

\section{REP- and ERIC-PCR}

The profiles generated with REP primers contained several bands, ranging in size from 0.1 to $5 \mathrm{~kb}$. REPPCR analysis revealed 18 different banding patterns (Table 1 and Fig. 1B). The DNA banding pattern obtained with primer combination ERICIR + ERIC2 was not as heterogeneous as that with REP-PCR. The profiles comprised 4-8 bands of $<2 \mathrm{~kb}$ and 13 different banding patterns were obtained. A $1.5-\mathrm{kb}$ fragment was present in $95 \%$ of the ERIC patterns (Fig. 1C). Strains belonging to the outbreak had the same profile by either REP-PCR or ERIC-PCR.

\section{ARDRA}

Primers complementary to rRNA regions that are wellconserved throughout the eubacterial kingdom were used to amplify two regions: (i) almost the entire $16 \mathrm{~S}$ rRNA gene; and (ii) a region between the genes coding for $16 \mathrm{~S}$ and $23 \mathrm{~S}$ rRNA plus a portion of the gene coding for 23S rRNA. The amplified products comprised a DNA fragment of $c .1 .5 \mathrm{~kb}$ for 16S rDNA (Fig. 2) and a fragment of $1.1 \mathrm{~kb}$ for $23 \mathrm{~S}$ rDNA + spacer (data not shown). Initially, only one PCR product was found in all the strains following either amplification strategy. Therefore, restriction digestions 


\section{A M1234567891011 12131415161718192021}

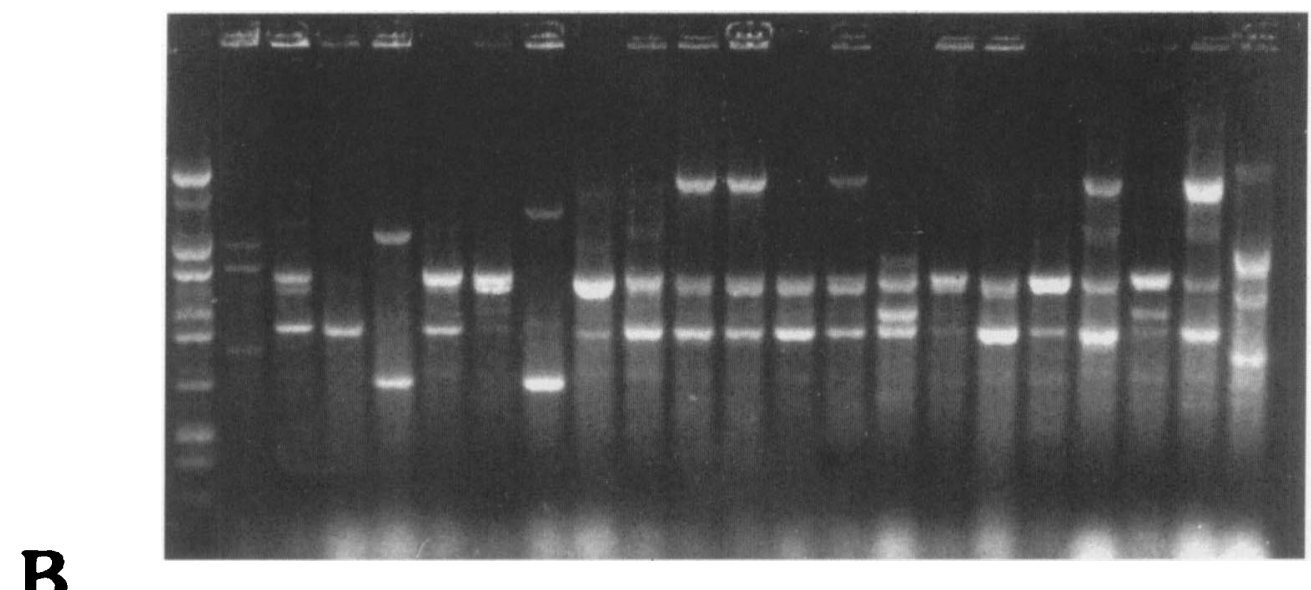

\section{$123456789101112131415161718192021 M$}

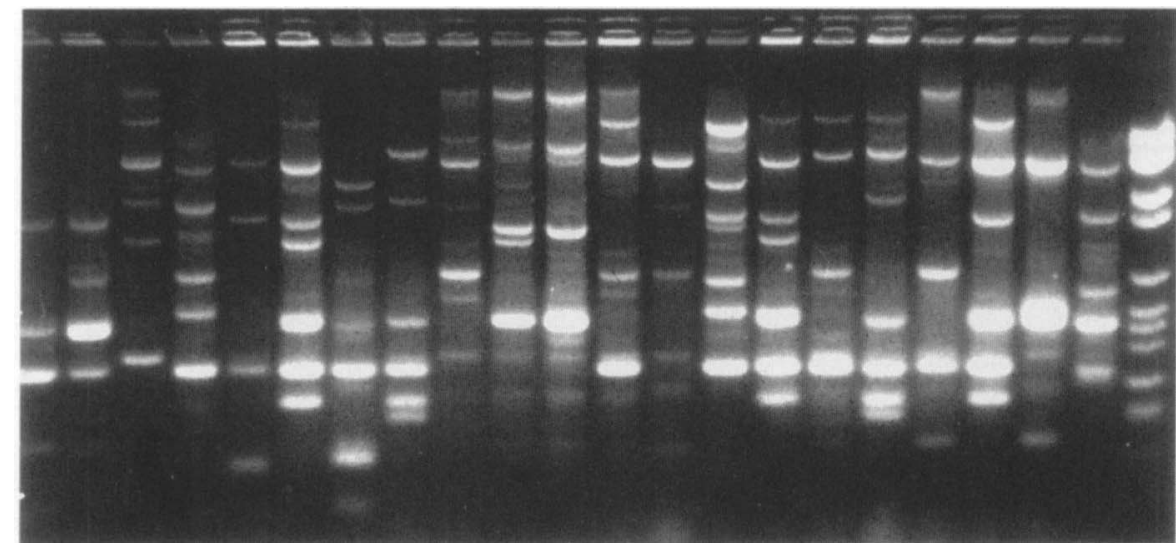

C

\section{$123456789101112131415161718192021 M$}

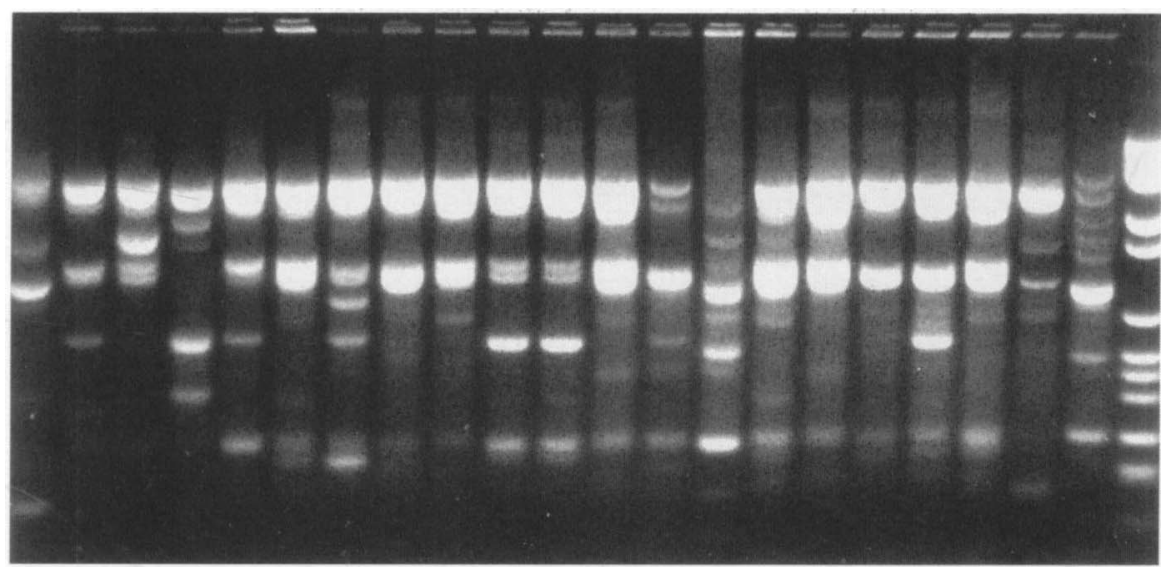

Fig. 1. Patterns obtained by PCR with: A, M13 forward primer; B, REP; C, ERIC. Lanes: M, DNA mol. wt marker VI (pBR328 DNA-Bgl I + pBR328-Hinf I); 1, strain 60; 2, strain 74; 3, strain 86; 4, strain 167; 5, strain 195; 6, strain 661; 7 , strain $37 ; 8$, strain $72 ; 9$, strain $61 ; 10$, strain $65 ; 11$, strain $31 ; 12$, strain $77 ; 13$, strain $183 ; 14$, strain $92 ; 15$, strain $41 ; 16$, strain $78 ; 17$, strain $58 ; 18$, strain $83 ; 19$, strain $188 ; 20$, strain $36 ; 21$, strain 68 .

were performed on the PCR amplicons and the resulting fragments were separated by electrophoresis: neither Dde I nor Hae III could differentiate between the isolates; Hinf I, Taq I, Rsa I and Hha I generated two patterns, as did Nla IV and Hph I but with a different distribution among the strains; $A l u$ I produced two patterns of different distribution; Hpa II was the only enzyme that generated three different patterns 
Table 1. Subdivision of isolates belonging to the $A$. calcoaceticus-A. baumannii complex by different PCR-based DNA fingerprinting techniques

\begin{tabular}{lcrrrrr}
\hline & & \multicolumn{5}{c}{ Number of patterns obtained with } \\
\cline { 3 - 6 } Strain no. & Outbreak & PFGE & AP-PCR & ERIC & REP & 16S rDNA-RFLP \\
\hline 60 & No & 12 & 1 & 1 & 1 & 1 \\
74 & No & 14 & 2 & 2 & 2 & 2 \\
86 & No & 9 & 3 & 3 & 3 & 3 \\
167 & No & 17 & 4 & 4 & 4 & 1 \\
195 & No & 21 & 2 & 5 & 5 & 2 \\
$1,6,21,23,39$, & Yes & 7 & 5 & 6 & 6 & 4 \\
41,661 & & & & & & \\
37 & No & 18 & 6 & 7 & 7 & 2 \\
72 & No & 11 & 2 & 6 & 8 & 3 \\
61 & No & 4 & 2 & 8 & 9 & 3 \\
65 & No & 10 & 7 & 9 & 10 & 3 \\
31 & No & 16 & 7 & 9 & 11 & 2 \\
77 & No & 1 & 2 & 10 & 12 & 2 \\
183 & No & 19 & 7 & 5 & 13 & 1 \\
92 & No & 20 & 8 & 11 & 14 & 2 \\
78 & No & 2 & 2 & 10 & 12 & 3 \\
58 & No & 8 & 2 & 6 & 8 & 2 \\
83 & No & 15 & 9 & 9 & 15 & 2 \\
188 & No & 5 & 8 & 6 & 16 & 5 \\
36 & No & 3 & 9 & 12 & 17 & 18 \\
68 & No & 13 & 10 & 13 & 18 & \\
\hline & & & & 5 & \\
\hline
\end{tabular}

${ }^{*}$ Results from reference 17.

(Table 2). As an example, the $H i n f I$ and $H p a$ II digests of PCR products from 16S rRNA genes of all types are shown in Fig. 2A and 2B. No polymorphisms were detected in $23 \mathrm{~S}+$ spacer regions with $H p a \mathrm{II}, R s a \mathrm{I}$ and $A l u \mathrm{I}$, while HinfI generated two different digestion patterns (data not shown). The other restriction enzymes were not used with $23 \mathrm{~S}+$ spacer PCR products.

\section{Discriminatory power and reproducibility}

The discrimination index and reproducibility of each typing method are shown in Table 3. ARDRA, with either 16S rRNA or $23 \mathrm{~S}+$ spacer PCR products, was the least discriminatory method with indices of 0.74 or $<0.50$, respectively. A combination of $\mathrm{Hpa}$ II and Hinf I increased the discrimination index from 0.6 ( $H p a$ II alone) to 0.72 , and with a combination of $H i n$ I, Hpa II, Alu I and Nla IV to 0.74. AP-PCR with M13 primer had a moderate discrimination index (0.87), while REP-PCR and ERIC-PCR both had a high discrimination index, although REP-PCR showed better reproducibility than ERIC-PCR.

\section{Discussion}

Nosocomial infections caused by organisms belonging to the A. calcoaceticus- $A$. baumannii complex are an increasing problem, especially in immunosuppressed patients, and have become a major cause of hospitalacquired infections worldwide. Rapid and accurate identification of strains involved in an outbreak is important, both for limiting the severity of the outbreak and for tracing the source of the infecting organism. Despite intensive investigations, no simple, sensitive, rapid and highly discriminatory system for typing members of the $A$. calcoaceticus- $A$. baumannii complex has so far emerged. Current typing methods are based on either phenotyping (e.g., antimicrobial susceptibility testing, biotyping, phage typing, protein electrophoresis) or genotypic analysis (e.g., plasmid analysis, restriction analysis of chromosomal DNA with or without pulsed-field gel electrophoresis). The relative advantages and disadvantages of these methods have been reviewed previously [27]. In general, genotypic methods have improved the ability to demonstrate differences between strains of nosocomial origin. Plasmid analysis has proved to be a useful means of demonstrating clonality among organisms involved in hospital epidemics [28], but is not ideal as $20-30 \%$ of $A$. calcoaceticus- $A$. baumannii strains do not contain plasmids [5,17], rendering them nontypable by this method. Ribotyping and low-frequency restriction analysis of chromosomal DNA are labourintensive processes and require several days for completion.

The present study investigated several PCR-based DNA-fingerprinting techniques. Such techniques have been used previously to delineate outbreaks [22-25], and seem to possess a high degree of discrimination, ease and speed. In AP-PCR, arbitrarily selected primers are annealed to the template DNA under low-stringency conditions for the initial cycles of DNA amplification, which allows interactions between the primers and target DNA in regions containing base mismatches. As these interactions may occur at multiple sites on both strands of a complex genome, only a single primer sequence is required for a given reaction. Graser et al. [22] amplified DNA from $A$. calcoaceticus-A. baumannii strains with a primer 


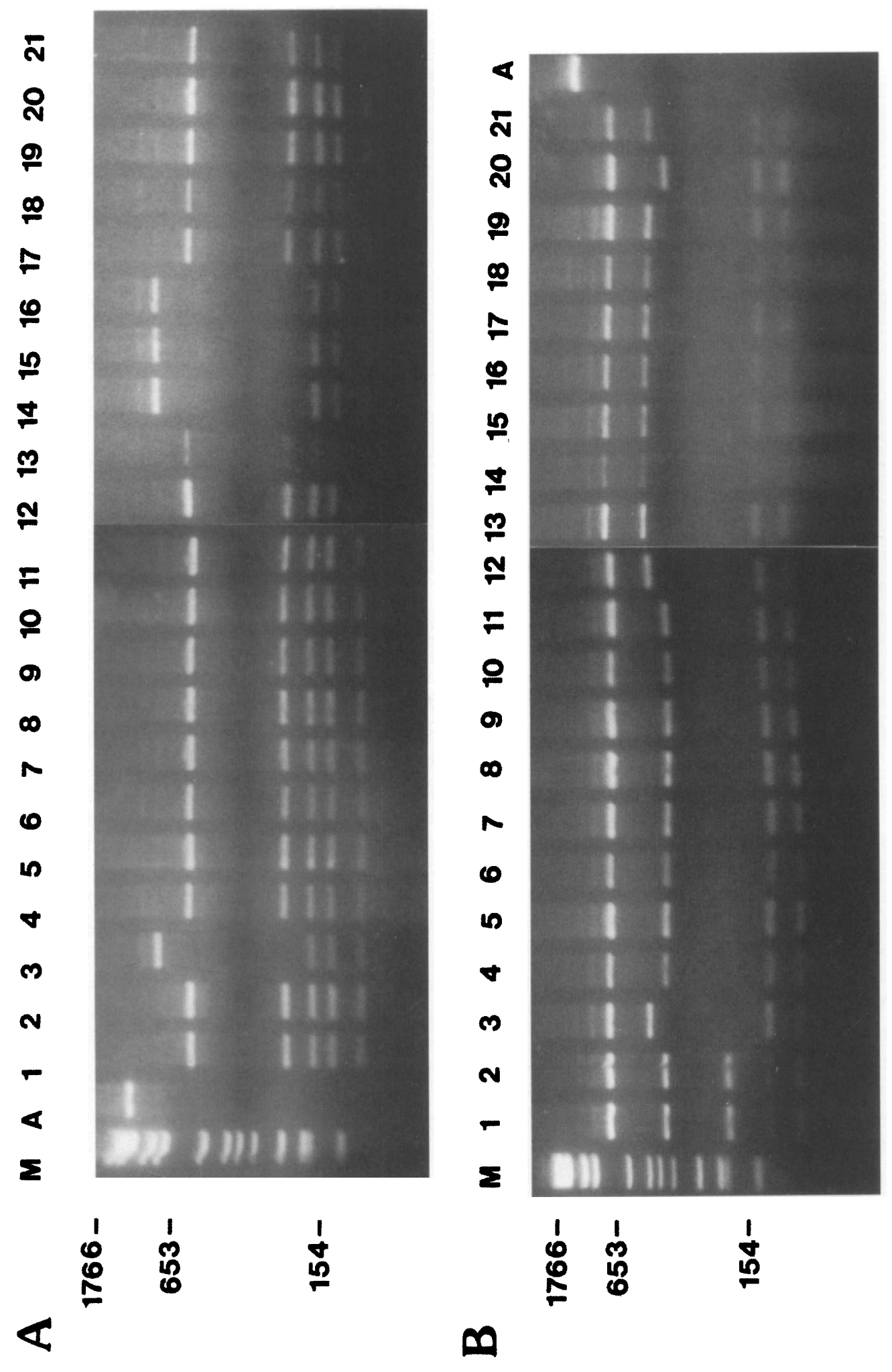

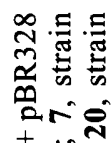

$=\ddot{\infty}$

$\infty . \pm$

交焉萦

60

Nin

2 我

응.․ㅠ. 중

5 के

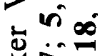

旁下余

घ.gn

可

iक

西至

$\langle\dot{8}$

ไี ถู

$\sum$ क

$\because \cdots$

芯造

毛

昰至

क्ष

$\oplus \ddot{\forall} \dot{0}$

实芒

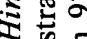

<-

这然

然

क

흥 흠

응

ำ

这

$<E_{\infty}^{\infty}$

范焉

을

용

政

过

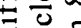

흘음

的

要=

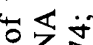

듬

등조폴

记

密

넌?

起苛

함든

这

矛诘a

0 으

< $<5$

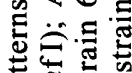

政

ते

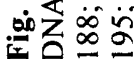


Table 2. Overview of ARDRA-16S rDNA patterns obtained for isolates belonging to the $A$. calcoaceticus-A. baumannii complex

\begin{tabular}{|c|c|c|c|c|c|c|}
\hline \multirow[b]{2}{*}{ Strain no. } & \multicolumn{6}{|c|}{ 16S rDNA-RFLP type } \\
\hline & $\operatorname{Hin} \mathrm{fI}$ & Hpa II & Alu I & Nal IV & Combined & Pattern no. \\
\hline 60 & B & B & B & B & BBBB & 1 \\
\hline 74 & A & $\mathrm{C}$ & B & A & ACBA & 2 \\
\hline 86 & A & B & B & $\mathbf{A}$ & ABBA & 3 \\
\hline 167 & B & B & B & B & BBBB & 1 \\
\hline 195 & A & $\mathrm{C}$ & B & A & ACBA & 2 \\
\hline $\begin{array}{l}1,3,21,23,39 \\
41,661\end{array}$ & A & A & A & A & AAAA & 4 \\
\hline 37 & A & $\mathrm{C}$ & B & A & ACBA & 2 \\
\hline 72 & A & B & B & A & ABBA & 3 \\
\hline 61 & A & $\mathrm{C}$ & B & A & ACBA & 2 \\
\hline 65 & A & B & B & A & ABBA & 3 \\
\hline 31 & A & B & B & A & ABBA & 3 \\
\hline 77 & A & C & B & A & ACBA & 2 \\
\hline 183 & A & $\mathrm{C}$ & B & A & ACBA & 2 \\
\hline 92 & B & B & B & B & BBBB & 1 \\
\hline 78 & A & $\mathrm{C}$ & B & A & ACBA & 2 \\
\hline 58 & A & B & B & A & ABBA & 3 \\
\hline 83 & A & $\mathrm{C}$ & B & A & ACBA & 2 \\
\hline 188 & A & $\mathrm{C}$ & B & A & ACBA & 2 \\
\hline 36 & B & B & B & B & BBBB & 1 \\
\hline 68 & A & B & B & B & ABBB & 5 \\
\hline
\end{tabular}

Table 3. Reproducibility and discriminatory index of several PCR-based DNA fingerprinting techniques for 26 isolates belonging to the $A$. calcoaceticus- $A$. baumannii complex

\begin{tabular}{lccc}
\hline Typing method & Number of types & Discrimination index & Reproducibility (\%) \\
\hline AP-PCR & 10 & 0.87 & 86 \\
REP-PCR & 18 & 0.99 & 90 \\
ERIC-PCR & 13 & 0.94 & 66 \\
ARDRA-16S* & 5 & 0.74 & 100 \\
ARDRA-23S & & & 100 \\
\hline
\end{tabular}

*Combination of the following restriction enzymes: HinfI, Hpa II, Alu I and Nla IV.

${ }^{\dagger} 23 \mathrm{~S}$ rDNA + spacer digested with HinfI.

consisting of the core sequence of the M13 phage, and found a discriminatory power similar to that of lowfrequency restriction analysis of chromosomal DNA. In contrast, the present study found a discrimination index of 0.87 for this technique, in comparison with an index of 1.0 for low-frequency restriction analysis of chromosomal DNA, which was considered to be the reference technique. In a previous study the discriminatory power of ribotyping and AP-PCR was very similar [23].

Another PCR-based fingerprinting technique was described by Versalovic et al. [29], who used consensus primers to amplify sequences located between successive repetitive elements - repetitive extragenic palindromic elements (REP) and enterobacterial repetitive intergenic consensus sequences (ERIC) - in gram-negative bacteria. REP and ERIC-based primers have also been used to investigate gram-positive bacteria, including Staphylococcus aureus [30] and Streptococcus pneumoniae [31]. In the present study, ERIC-PCR had a higher discrimination index than AP-PCR, but a lower discrimination index than REP-PCR and low-frequency restriction analysis of chromosomal DNA. Reboli et al. [25] applied REP and ERIC-PCR to characterise $A$. baumannii isolates from adult intensive care units, and also found that REP-PCR was more effective in discriminating strains than ERIC-PCR. In contrast, Struelens et al. [24] found agreement between ERIC-PCR and low-frequency restriction analysis of chromosomal DNA when investigating an outbreak of infections caused by $A$. baumannii.

Ribosomal operons have also been targeted for PCRRFLP typing. Results from 16S rDNA analysis are useful for identification to the species level [32], including identification of Acinetobacter spp. [33], but are not useful for typing members of the $A$. calcoaceticus- $A$. baumannii complex, as shown in this study and others [33]. In the present study, the difference between ARDRA-16S profiles A (five DNA fragments) and $B$ (four DNA fragments) generated by digestion with HinfI (Fig. 2A) could result from loss of a Hinf I site, since the size ( $c$. $1.1 \mathrm{~kb})$ of the large DNA fragment in profile $B$ is the sum of the sizes of the 789-bp and 300-bp DNA fragments of profile $A$. The difference observed 
between profiles A (five DNA fragments) and B (four DNA fragments) generated by digestion with $H p a$ II (Fig. 2B) could be explained if the genomic DNA from Acinetobacter contained two or more copies of 16S rDNA. Loss of an Hpa II site from one or more of the copies could generate profile A from profile B as profile A showed an extra 200-bp DNA fragment (i.e., the sum of the 130-bp and 70-bp fragments from profile $B)$. The heterogeneity in one or more copies of 16S rDNA is also suggested by a reproducible decrease in the intensity of the 130-bp and 70-bp fragments, indicating that there is less DNA present. Thus, although slight differences are observed between the ARDRA-16S patterns, the strains studied probably belong to the same species of the A. calcoaceticus- $A$. baumannii complex. The intergenic spacer region between the genes coding for 16S rRNA and 23S rRNA is useful for identification of eubacteria [34] and for typing Rochalima henselae [35], but in the present study with ARDRA of $23 \mathrm{~S}$ rDNA + spacer, despite the high reproducibility demonstrated, only limited variation was found among the $A$. calcoaceticus- $A$. baumannii strains examined, thereby showing a low discrimination index.

In conclusion, REP-PCR was found to be a rapid method, with a high degree of reproducibility and discriminatory power, which seems to be well-suited for epidemiological studies of strains belonging to the $A$. calcoaceticus- $A$. baumannii complex.

This work was supported in part by grants DGICYT-Spain (PB-92/ 0212 and 93/1229).

\section{References}

1. Beck-Sagué CM, Jarvis WR, Brook JH et al. Epidemic bacteremia due to Acinetobacter baumannii in five intensive care units. Am J Epidemiol 1990; 132: 723-733.

2. Castle M, Tenney JH, Weinstein MP, Eickhoff TC. Outbreak of a multiply resistant Acinetobacter in surgical intensive care unit: epidemiology and control. Heart Lung 1978; 7: 641-644.

3. French GL, Casewell MW, Roncoroni AJ, Knight S, Phillips I. A hospital outbreak of antibiotic-resistant Acinetobacter anitratus: epidemiology and control. J Hosp Infect 1980; 1: 125-131.

4. Hartstein AI, Morthland VH, Rourke JW et al. Plasmid DNA fingerprinting of Acinetobacter calcoaceticus subspecies anitratus from intubated and mechanically ventilated patients. Infect Control Hosp Epidemiol 1990; 11: 531-538.

5. Marcos MA, Abdalla S, Pedraza F et al. Epidemiological markers of Acinetobacter baumannii clinical isolates from a Spinal Cord Injury Unit. $J$ Hosp Infect 1994; 28: 39-48.

6. Vila J, Almela M, Jimenez de Anta MT. Laboratory investigation of hospital outbreak caused by two different multiresistant Acinetobacter calcoaceticus subsp. anitratus strains. J Clin Microbiol 1989; 27: 1086-1089.

7. Allen KD, Green HT. Hospital outbreak of multi-resistant Acinetobacter anitratus: an airborne mode of spread? $J$ Hosp Infect 1987; 9: 110-119.

8. Bouvet PJM, Jeanjean S, Vieu J-F, Dijkshoorn L. Species, biotype, and bacteriophage type determinations compared with cell envelope protein profiles for typing Acinetobacter strains. $J$ Clin Microbiol 1990; 28: 170-176.

9. Kropec A, Hubner J, Daschner FD. Comparison of three typing methods in hospital outbreaks of Acinetobacter calcoaceticus infection. $J$ Hosp Infect 1993; 23: 133-142.
10. Traub WH. Acinetobacter baumannii serotyping for delineation of outbreaks of nosocomial cross-infection. J Clin Microbiol 1989; 27: 2713-2716.

11. Alexander M, Ismail F, Jackson PJH, Noble WC. Fingerprinting Acinetobacter strains from clinical sources by numerical analysis of electrophoretic protein patterns. $J$ Med Microbiol 1984; 18: 55-64.

12. Vila J, Canales MA, Marcos MA, Gomez-Lus R, Jimenez de Anta MT. Molecular epidemiological analysis of nosocomial Acinetobacter baumannii isolates. In: Towner KJ, BergogneBérézin E, Fewson CA (eds) The biology of Acinetobacter. Taxonomy, clinical importance, molecular biology, physiology, industrial relevance. New York, Plenum Press. 1991: 69-76.

13. Dijkshoorn L, Van Vianen W, Degener JE, Michel MF. Typing of Acinetobacter calcoaceticus strains isolated from hospital patients by cell envelope protein profiles. Epidemiol Infect 1987; 99: 659-667.

14. Dijkshoorn L, Michel MF, Degener JE. Cell envelope protein profiles of Acinetobacter calcoaceticus strains isolated in hospitals. J Med Microbiol 1987; 23: 313-319.

15. Gerner-Smidt P. Ribotyping of the Acinetobacter calcoaceticusAcinetobacter baumannii complex. J Clin Microbiol 1992; 30: 2680-2685.

16. Allardet-Servent A, Bouziges N, Carles-Nurit M-J, Bourg G, Gouby A, Ramuz M. Use of low-frequency-cleavage restriction endonucleases for DNA analysis epidemiological investigations of nosocomial bacterial infections. J Clin Microbiol 1989; 27: 2057-2061.

17. Marcos MA, Jimenez de Anta MT, Vila J. Correlation of six methods for typing nosocomial isolates of Acinetobacter baumannii. J Med Microbiol 1995; 42: 328-335.

18. Lupski JR. Molecular mechanisms for transposition of drugresistance genes and other movable genetic elements. Rev Infect Dis 1987; 9: 357-368.

19. Ménard C, Brousseau R, Mouton C. Application of polymerase chain reaction with arbitrary primer (AP-PCR) to strain identification of Porphyromonas (Bacteroides) gingivalis. FEMS Microbiol Lett 1992; 95: 163-168.

20. Niesters HGM, Goessens WHF, Meis JFMG, Quint WGV. Rapid polymerase chain reaction-based identification assays for Candida species. J Clin Microbiol 1993; 31: 904-910.

21. Struelens MJ, Bax R, Deplano A, Quint WGV, Van Belkum A. Concordant clonal delineation of methicillin-resistant Staphylococcus aureus by macro restriction analysis and polymerase chain reaction genome fingerprinting. J Clin Microbiol 1993; 31: $1964-1970$.

22. Gräser Y, Klare I, Halle E et al. Epidemiological study of an Acinetobacter baumannii outbreak by using polymerase chain reaction fingerprinting. J Clin Microbiol 1993; 31: 2417-2420.

23. Vila J, Marcos A, Llovet T, Coll P, Jimenez de Anta T. A comparative study of ribotyping and arbitrarily primed polymerase chain reaction for investigation of hospital outbreaks of Acinetobacter baumannii infection. $J$ Med Microbiol 1994; 41: 244-249.

24. Struelens MJ, Carlier E, Maes N, Serruys E, Quint WG, Van Belkum A. Nosocomial colonization and infection with multiresistant Acinetobacter baumannii: outbreak delineation using DNA macrorestriction analysis and PCR-fingerprinting. $J$ Hosp Infect 1993; 25: 15-32.

25. Reboli AC, Houston ED, Monteforte JS, Wood CA, Hamill RJ. Discrimination of epidemic and sporadic isolates of Acinetobacter baumannii by repetitive element PCR-mediated DNA fingerprinting. $J$ Clin Microbiol 1994; 32: 2635-2640.

26. Bouvet PJM, Grimont PAD. Taxonomy of the genus Acinetobacter with the recognition of Acinetobacter baumannii sp. nov., Acinetobacter haemolyticus sp. nov., Acinetobacter johnsonii sp. nov., and Acinetobacter junii sp. nov., and emended descriptions of Acinetobacter calcoaceticus and Acinetobacter lwoffii. Int $J$ Syst Bacteriol 1986; 36: 228-240.

27. Marcos MA, Vila J, Jimenez de Anta MT. Epidemiologia de las infecciones de Acintobacter baumannii. Enfer Infec Microbiol Clin 1993; 11: 29-33.

28. Wachsmuth K. Molecular epidemiology of bacterial infections: examples of methodology and of investigations of outbreaks. Rev Infect Dis 1986; 8: 682-692.

29. Versalovic J, Koeuth T, Lupski JR. Distribution of repetitive DNA sequences in eubacteria and application to fingerprinting of bacterial genomes. Nucleic Acids Res 1991; 19: 6823-6831.

30. Van Belkum A, Bax R, Peerbooms P, Goessens WHF, Van Leeuwen N, Quint WGV. Comparison of phage typing and 
DNA fingerprinting by polymerase chain reaction for discrimination of methicillin-resistant Staphylococcus aureus strains. J Clin Microbiol 1993; 31: 798-803.

31. Versalovic J, Kapur V, Mason EO et al. Penicillin-resistant Streptococcus pneumoniae strains recovered in Houston: identification and molecular characterization of multiple clones. J Infect Dis 1993; 167: 850-856.

32. Gurtler V, Wilson VA, Mayall BC. Classification of medically important clostridia using restriction endonuclease site differences of PCR-amplified 16S rDNA. J Gen Microbiol 1991; 137: 2673-2679.
33. Vaneechoutte M, Dijkshoorn L, Tjernberg I et al. Identification of Acinetobacter genomic species by amplified ribosomal DNA restriction analysis. $J$ Clin Microbiol 1995; 33: 11-15.

34. Barry T, Colleran G, Glennon M, Dunican LK, Gannon F. The $16 \mathrm{~S} / 23 \mathrm{~S}$ ribosomal spacer region as a target for DNA probes to identify eubacteria. PCR Methods Applic 1991; 1: 51-56.

35. Matar GM, Swaminathan B, Hunter SB, Slater LN, Welch DF. Polymerase chain reaction-based restriction fragment length polymorphism analysis of a fragment of the ribosomal operon from Rochalima species for subtyping. J Clin Microbiol 1993; 31: 1730-1734. 